\title{
ANALISIS LAJU KESEMBUHAN PASIEN DEMAM BERDARAH DENGUE DENGAN MENGGUNAKAN MODEL REGRESI COX PROPORTIONAL HAZARD
}

\author{
FITRI AULIA, FERRA YANUAR, IZZATI RAHMI HG \\ Program Studi S1 Matematika, \\ Fakultas Matematika dan Ilmu Pengetahuan Alam, Universitas Andalas, \\ Kampus UNAND Limau Manis Padang, Indonesia, \\ fitriaulia72@gmail.com,ferrayanuar@sci.unand.ac.id,izzatirahmihg@sci.unand.ac.id
}

Diterima 17 Februari 2020 Direvisi 7 Maret $2020 \quad$ Dipublikasikan 29 April 2020

\begin{abstract}
Abstrak. Demam Berdarah Dengue (DBD) merupakan salah satu penyakit berbahaya dan bisa meyebabkan kematian. Untuk mengurangi angka kematian akibat demam berdarah dengue, maka penelitian ini akan memodelkan waktu survival dengan studi kasus pada pasien demam berdarah dengue yang dirawat di Rumah Sakit Umum Pusat (RSUP) Dr. M. Djamil Padang pada tahun 2014. Metode yang digunakan adalah analisis survival dengan model regresi Cox Proportional Hazard. Berdasarkan hasil seleksi model diperoleh faktor yang mempengaruhi laju kesembuhan pasien demam berdarah dengue yaitu umur dan jumlah trombosit.
\end{abstract}

Kata Kunci: Laju kesembuhan, analisis survival, regresi Cox Proportional Hazard

\section{Pendahuluan}

Demam berdarah Dengue (DBD) tergolong penyakit yang menular dan dapat menyebabkan kematian, penderita DBD perlu penanganan dan perawatan di rumah sakit selama beberapa waktu sampai penderita dinyatakan sembuh. Laju kesembuhan berhubungan dengan data lamanya pasien dirawat. Analisis data yang dapat dilakukan dalam menganalisis laju kesembuhan adalah analisis survival. Analisis survival merupakan salah satu teknik statistika yang digunakan untuk memodelkan data ketahanan hidup sampai terjadinya suatu kejadian tertentu [3]. Dalam makalah ini akan dilakukan analisis laju kesembuhan pasien DBD dengan menggunakan model regresi Cox Proportional Hazard pada pasien yang dirawat di Bangsal Tropik dan Infeksi Penyakit Dalam Rumah Sakit Umum Pusat (RSUP) Dr. M. Djamil Padang pada tahun 2014.

*penulis korespondensi 
116 Fitri Aulia dkk.

\section{Landasan Teori}

\subsection{Regresi Cox Proportional Hazard}

Pemodelan regresi Cox Proportional Hazard digunakan untuk mengetahui hubungan antara waktu survival dengan variabel-variabel yang diduga mempengaruhi waktu survival. Bentuk umum dari model Cox Proportional Hazard untuk individu ke-i adalah [2] :

$$
h_{i}(t)=h_{0}(t) \exp \left(\beta_{1} x_{1 i}+\beta_{2} x_{2 i}+\cdots+\beta_{p} x_{p i}\right) .
$$

$h_{i}(t)$ merupakan fungsi hazard individu ke- $i$ pada waktu ke $t, h_{0}(t)$ fungsi baseline hazard. Selanjutnya $\beta_{1}, \beta_{2}, \cdots, \beta_{p}$ adalah parameter regresi, sedangkan $x_{1 i}, x_{2 i}, \cdots, x_{p i}$ nilai variabel bebas $X_{1}, X_{2}, \cdots, X_{p}$ untuk individu ke- $i$.

\subsection{Estimasi Parameter Model}

Metode maksimum likelihood adalah salah satu metode penduga parameter $\beta$ pada model regresi Cox Proportional Hazard. Fungsi likelihood dapat dinyatakan sebagai berikut:

$$
L(\beta)=\prod_{i=1}^{r} \frac{\exp \left(\sum_{j=1}^{p}\left(\beta_{j} x_{j(i)}\right)\right)}{\sum_{I \in R\left(t_{i}\right)} \exp \left(\sum_{j=1}^{p}\left(\beta_{j} x_{j(l)}\right)\right)}
$$

\subsection{Pemeriksaan Asumsi Cox Proportional Hazard}

Pemeriksaan asumsi Cox Proportional Hazard salah satunya dapat dilakukan dengan mencari nilai Schoenfeld residual. Koefisien korelasi Pearson dinyatakan dengan: [4]

$$
r_{\left(w, e_{j}\right)}=\frac{r \sum_{i}^{r} w_{i} R_{j i}-\sum_{i}^{r} w_{i} \sum_{i}^{r} R_{j i}}{\sqrt{r \sum_{i}^{r} w_{i}^{2}-\left(\sum_{i}^{r} w_{i}\right)^{2}} \sqrt{r \sum_{i}^{r} R_{j i}^{2}-\left(\sum_{i}^{r} R_{j i}\right)^{2}}}
$$

\subsection{Pengujian Signifikansi Parameter}

Uji signifikansi parameter ada dua, yaitu:

(1) Uji Serentak.

Uji serentak digunakan untuk mengetahui apakah secara keseluruhan parameter signifikan dengan model.

$H_{0}: \beta_{1}=\beta_{2}=\cdots=\beta_{p}=0$.

$H_{1}$ : paling sedikit ada satu $\beta_{h} \neq 0$ dengan $h=1,2, \cdots, p$.

Statistik uji G adalah:

$$
G^{2}=-2\left(\ln L_{R}-\ln L_{F}\right)
$$


Jika diperoleh $G^{2}>X_{(p, \alpha)}^{2}$ maka diputuskan untuk menolak $H_{0}$.

(2) Uji Parsial

Uji Parsial dilakukan untuk mengetahui apakah setiap variabel bebas signifikan terhadap model.

Hipotesis yang di uji :

$H_{0}: \beta_{h}=0$, dengan $h=1,2, \cdots, p$.

$H_{1}: \beta_{h} \neq 0$. Statistik uji Wald adalah :

$$
W^{2}=\left[\frac{{\widehat{\beta_{h}}}^{2}}{S E\left(\widehat{\beta_{h}}\right)}\right]^{2} .
$$

Jika diperoleh $G^{2}>X_{(\alpha, 1)}^{2}$ maka diputuskan untuk menolak $H_{0}$.

\subsection{Seleksi Model Terbaik}

Nilai AIC diperoleh dari [2] :

$$
A I C=-2 \log \widehat{L}+2 p
$$

\subsection{Rasio Hazard}

Rasio hazard didefinisikan dengan [3] :

$$
\text { Rasiohazard }=\exp \left\{{ }^{\prime}\left(x^{*}-x\right)\right\} .
$$

\section{Metode Penelitian}

Data yang digunakan dalam penelitian ini adalah data sekunder yang diperoleh dari hasil penelitian Benazir Jan Binti Allhammulhack yang disajikan dalam skripsi Karakteristik Pasien Demam Berdarah Dengue di Bangsal Tropik \& Infeksi Penyakit Dalam RSUP Dr. M. Djamil Padang pada Tahun 2014 [1]. Data rekam medis tersebut diperoleh dari rekam medis RSUP Dr. M. Djamil pada 1 Januari 2014 sampai 30 Desember 2014. Variabel yang digunakan dalam penelitian ini adalah waktu survival berupa lamanya pasien dirawat $(Y)$. Variabel prediktor yang diasumsikan mempengaruhi laju kesembuhan adalah umur $\left(X_{1}\right)$, kadar hemoglobin saat pertama kali pasien masuk rumah sakit $\left(X_{2}\right)$, kadar hemoglobin tertinggi selama pasien dirawat $\left(X_{3}\right)$ dan jumlah trombosit $\left(X_{4}\right)$.

Tahapan penelitian yang dilakukan dalam menganalisis data untuk mendapatkan model regresi Cox Proportional Hazard terhadap faktor-faktor yang mempengaruhi laju kesembuhan pasien DBD adalah:

(1) Melakukan estimasi parameter model regresi Cox Proportional Hazard dengan menggunakan metode penduga maksimum likelihood.

(2) Membentuk model awal regresi Cox Proportional Hazard.

(3) Melakukan pemeriksaan asumsi Cox Proportional Hazard.

(4) Melakukan uji signifikansi parameter dengan uji serentak dan uji parsial. 
(5) Membentuk model regresi Cox Proportional Hazard sesuai dengan variabel bebas yang berpengaruh secara signifikan.

(6) Menentukan model terbaik dengan kriteria AIC.

(7) Menghitung rasio hazard dari variabel bebas yang berpengaruh secara signifikan terhadap model untuk mengetahui laju kesembuhan pada setiap kategori variabel bebas.

(8) Penarikan kesimpulan setelah didapatkan model Regresi Cox Proportional Hazard pada data pasien DBD dan interpretasi model.

\section{Pembahasan}

Dari 137 pasien DBD terdapat 14 pasien yang tidak diamati secara utuh, karena individu tersebut keluar atau hilang sebelum pengamatan berakhir, sehingga dapat disimpulkan bahwa data tersebut tersensor tipe III.

\begin{tabular}{|c|c|c|}
\hline Variabel Bebas & DugaanParameter $(\widehat{\beta})$ & Standar Error \\
\hline$X_{1}$ & $-0,015$ & 0,008 \\
\hline$X_{2}$ & 0,139 & 0,086 \\
\hline$X_{3}$ & 0,139 & 0,086 \\
\hline$X_{4}$ & 0,003 & 0,002 \\
\hline
\end{tabular}

Tabel 1. Estimasi Parameter Model Regresi Cox Proportional Hazard.

Dari Tabel 1 diperoleh model regresi Cox Proportional Hazard sebagai berikut

$$
\widehat{(h(t))}=h_{0}(t) \exp \left(-0,015 X_{1}+0,139 X_{2}-0,120 X_{3}+0,003 X_{4}\right) .
$$

Selanjutnya, dilakukan pemeriksaan asumsi Cox Proportional Hazard terhadap semua variabel bebas.

\begin{tabular}{|l|c|c|l|}
\hline \multicolumn{1}{|c|}{ Variabel } & $\begin{array}{l}\text { Koef. Korelasi } \\
\text { Pearson }\end{array}$ & $\boldsymbol{t}_{\text {hit }}$ & \multicolumn{1}{|c|}{ Kesimpulan } \\
\hline $\begin{array}{l}\text { Rank Survival Time dengan } \\
\text { Schoenfeld residual } X_{1}\end{array}$ & $-0,131$ & $-1,49$ & $\begin{array}{l}\text { Tidak } \\
\text { Berkorelasi }\end{array}$ \\
\hline $\begin{array}{l}\text { Rank Survival Time dengan } \\
\text { Schoenfeld Residual } X_{2}\end{array}$ & 0,154 & 1,70 & $\begin{array}{l}\text { Tidak } \\
\text { Berkorelasi }\end{array}$ \\
\hline $\begin{array}{l}\text { Rank Survival Time dengan } \\
\text { Schoenfeld Residual } X_{3}\end{array}$ & 0,228 & 2,60 & $\begin{array}{l}\text { Tidak } \\
\text { Berkorelasi }\end{array}$ \\
\hline $\begin{array}{l}\text { Rank Survival Time dengan } \\
\text { Schoenfeld Residual } X_{4}\end{array}$ & $-0,239$ & $-2,71$ & $\begin{array}{l}\text { Tidak } \\
\text { Berkorelasi }\end{array}$ \\
\hline
\end{tabular}

Tabel 2. Nilai Korelasi Pearson antara Rank Survival Time dengan Schoenfeld Residual

Berdasarkan Tabel 2 terlihat bahwa semua variabel memenuhi asumsi Cox Proportional Hazard karena tidak terdapat korelasi antara survival time dengan Schoenfeld residual. Uji signifikansi Cox Proportional Hazard parameter untuk model dapat 
dilakukan. Hipotesis uji sebagai berikut :

$H_{0}: \beta_{h}=0$, dengan $h=1,2, \cdots, p$.

$H_{1}: \beta_{h} \neq 0$.

pada taraf nyata $\alpha=0,1$ dan derajat bebas $=4$ diperoleh $\chi_{(\alpha, 4)}^{2}=7,779$ dan $G^{2}=9,266$. Nilai $G^{2}$ yang didapatkan lebih besar $\chi_{\text {tabel }}^{2}$ sehingga $H_{0}$ ditolak, artinya terdapat variabel bebas yang signifikan terhadap model. Berikut uji parsial terhadap variabel bebas:

\begin{tabular}{|c|c|c|c|c|c|c|}
\hline $\begin{array}{c}\text { Variabel } \\
\text { Bebas }\end{array}$ & $\begin{array}{c}\text { Dugaan } \\
\text { Parameter } \\
(\widehat{\beta})\end{array}$ & $\begin{array}{c}\text { Standar } \\
\text { Error }\end{array}$ & $\begin{array}{l}\text { Wald } \\
\left(W^{2}\right)\end{array}$ & Df & p-value & $\operatorname{Exp}(\widehat{\beta})$ \\
\hline$X_{1}$ & $-0,015$ & 0,008 & 3,982 & 1 & 0,046 & 0,985 \\
\hline$X_{2}$ & 0,139 & 0,086 & 2,620 & 1 & 0,105 & 1,149 \\
\hline$X_{3}$ & $-0,120$ & 0,094 & 1,640 & 1 & 0,200 & 0,887 \\
\hline$X_{4}$ & 0,003 & 0,002 & 4,712 & 1 & 0,030 & 1,003 \\
\hline
\end{tabular}

Tabel 3. Estimasi Parameter Model secara Parsial

Berdasarkan Tabel 3 terlihat bahwa variabel umur dan trombosit berpengaruh signifikan dengan menggunakan taraf nyata $\alpha=0,1$. Untuk memperoleh model terbaik maka kedua variabel yang signifikan tersebut diuji kembali.

\begin{tabular}{|c|c|c|c|c|c|c|}
\hline $\begin{array}{c}\text { Variabel } \\
\text { Bebas }\end{array}$ & \begin{tabular}{|c} 
Dugaan \\
Parameter \\
$(\widehat{\beta})$
\end{tabular} & $\begin{array}{c}\text { Standar } \\
\text { Error }\end{array}$ & $\begin{array}{l}\text { Wald } \\
\left(\boldsymbol{W}^{2}\right)\end{array}$ & Df & $p$-value & $\operatorname{Exp}(\widehat{\beta})$ \\
\hline$X_{1}$ & $-0,014$ & 0,008 & 3,412 & 1 & 0,065 & 0,986 \\
\hline$X_{4}$ & 0,003 & 0,002 & 5,117 & 1 & 0,024 & 1,003 \\
\hline
\end{tabular}

Tabel 4. Estimasi Parameter Model Regresi Cox Proportional Hazard II

Hasil analisis yang disajikan pada Tabel 4 mengindikasikan bahwa estimasi parameter sudah signifikan. Sehingga variabel umur dan trombosit berpengaruh terhadap model. Model regresi Cox Proportional Hazard II yang terbentuk:

$$
\widehat{(h(t))}=h_{0}(t) \exp \left(-0,014 X_{1}+0,003 X_{4}\right) \text {. }
$$


Model Cox Proportional Hazard yang telah didapatkan selanjutnya akan diperiksa manakah model terbaik untuk memodelkan data.

\begin{tabular}{|l|c|c|}
\hline \multicolumn{1}{|c|}{ Model } & AIC & Ranking \\
\hline $\begin{array}{l}\text { Regresi Cox proportional hazard I } \\
\left.\text { (dengan variabel bebas } X_{1}, X_{2}, X_{3}, X_{4}\right)\end{array}$ & 17,266 & 2 \\
\hline $\begin{array}{l}\text { Regresi Cox proportional hazard II } \\
\text { (dengan variabel bebas } X_{1}, X_{4} \text { ) }\end{array}$ & 10,284 & 1 \\
\hline
\end{tabular}

Tabel 5. Nilai AIC untuk setiap kandidat model.

Berdasarkan Tabel 5, diperoleh model terbaik sebagai berikut :

$$
h(t)=h_{0}(t) \exp \left(-0,014 X_{1}+0,003 X_{4}\right) .
$$

Perhitungan rasio hazard dilakukan untuk mengetahui laju kesembuhan pengobatan pasien DBD yang menjalani perawatan di RSUP M. Djamil Padang berdasarkan variabel bebas yang berpengaruh secara signifikan. Hasil rasio hazard pasien berumur di atas 50 tahun lama rawatannya 0,5670 kali lebih lama dibandingkan dengan pasien berumur dibawah 20 tahun dan rasio hazard untuk variabel trombosit adalah pasien dengan trombosit diatas $150 \mathrm{ml}$ lama rawatannya 20,08 kali lebih cepat dibandingkan dengan pasien dengan trombosit dibawah $150 \mathrm{ml}$.

\section{Kesimpulan}

Dari nilai AIC terkecil yang diperoleh dapat disimpulkan bahwa faktor yang berpengaruh secara signifikan terhadap laju kesembuhan pasien DBD adalah umur dan jumlah trombosit. Model regresi Cox Proportional Hazard adalah sebagai berikut:

$$
h(t)=h_{0}(t) \exp \left(-0,014 X_{1}+0,003 X_{4}\right) .
$$

\section{Daftar Pustaka}

[1] Allhammulhack, B. J. B. 2016. Karakteristik Pasien Demam Berdarah Dengue di Bangsal Tropik \& Infeksi Penyakit Dalam RSUP Dr. M. Djamil Padang pada Tahun 2014. Skripsi (Padang : Universitas Andalas, 2016).

[2] Collet, D. 2003. Modelling Survival Data in Medical Research. Second Edition. London : Chapman and Hall.

[3] Kleinbaum, D.G dan Klein, M. 2012. Survival Analysis: A Self Learning Text. Third Edition. New York : Springer.

[4] Walpole, R.E, 1993. Pengantar Statistika. Edisi Ketiga. Jakarta: Gramedia Pustaka Utama. 